\title{
Dyskryminacja słuchowa w zakresie częstotliwości, intensywności i czasu trwania dźwięku - podstawy teoretyczne - przegląd literatury
}

\section{Auditory discrimination of frequency, intensity and duration - theoretical basis - a review}

\author{
Karolina Dajos-Krawczyńska \\ Instytut Fizjologii i Patologii Słuchu, Światowe Centrum Słuchu, Warszawa/Kajetany \\ Adres autora: Karolina Dajos-Krawczyńska, Światowe Centrum Słuchu, Kajetany, ul. Mokra 17, \\ 05-830 Nadarzyn, e-mail: k.dajos@gmail.com
}

\begin{abstract}
Streszczenie
Dyskryminacja słuchowa, jako jedna z funkcji słuchowych, pozwala na identyfikację, rozpoznawanie, rozróżnianie i rozumienie dźwięków. Dyskryminacja słuchowa to miara zdolności układu słuchowego do rozróżniania wrażeń związanych ze zmianą określonej wielkości fizycznej dźwięku - jego częstotliwości, intensywności i czasu trwania. Umiejętność dyskryminacji jest szczególnie ważna w procesie rozumienia mowy. Celem pracy było omówienie podstaw teoretycznych zdolności dyskryminacji słuchowej oraz wskazanie dostępnych metod i testów badania tych funkcji słuchowych.
\end{abstract}

Słowa kluczowe: dyskryminacja słuchowa • intensywność dźwięku • częstotliwość • czas trwania

\begin{abstract}
The auditory discrimination, as one of the auditory functions, allows the identification, recognition, differentiation and understanding of sounds, especially speech sounds. The auditory discrimination is the measure of the ability of the auditory system to distinguish sensations associated with changes in certain physical features of sounds - frequency, intensity and duration. The ability of the auditory discrimination is particularly important for speech understanding. The aim of this paper was to discuss theoretical basis of auditory discrimination and to indicate available tests and assessment methods.
\end{abstract}

Key words: auditory discrimination $\bullet$ sound intensity $\bullet$ frequency $\bullet$ duration

\section{Wprowadzenie}

Podstawowa umiejętność, która umożliwia identyfikację, rozpoznawanie i rozumienie dźwięków (w tym również dźwięków mowy), to dyskryminacja słuchowa. Pozwala ona na detekcję modulacji amplitudowych i częstotliwościowych z taką rozdzielczością czasową, która umożliwia rozumienie zarówno wolnych, jak i szybkich zmian dźwięków mowy w czasie wypowiedzi. Dodatkowo zdolności dyskryminacji słuchowej stanowią podstawę odróżniania dźwięków mowy od dźwięków tła akustycznego (w tym również innych dźwięków mowy).

Dyskryminacja jest to miara zdolności układu słuchowego do rozróżniania wrażeń związanych ze zmianą określonej wielkości fizycznej opisującej dźwięk - częstotliwości, intensywności i czasu trwania. Najmniejszą rozpoznawalną różnicę pomiędzy dwoma bodźcami nazywa się progiem różnicowania lub progiem dyskryminacji [1].
Zdolność dyskryminacji słuchowej jest rozwijana już od urodzenia. U niemowląt dyskryminacja słuchowa jest na tyle rozwinięta, aby pozwalała na odróżnianie i identyfikację istotnych kontrastów językowych, natomiast w wieku 6 miesięcy dzieci mają już prawdopodobnie wykształcone umiejętności wydzielania fonetycznie istotnych szczegółów dźwięków mowy. Poziom dyskryminacji słuchowej zbliżony do poziomu osób dorosłych dzieci uzyskują około 10-12 roku życia. Jednak wraz z wiekiem zdolności dyskryminacji słuchowej zmniejszają się - osoby w wieku podeszłym zwykle mają słabsze progi różnicowania niż młode osoby dorosłe.

Celem pracy było omówienie podstaw teoretycznych zdolności dyskryminacji częstotliwości, intensywności i czasu trwania dźwięków, a także omówienie metod, procedur i testów służących do oceny progów różnicowania poszczególnych cech akustycznych dźwięków. 


\section{Dyskryminacja słuchowa w zakresie intensywności}

Narząd słuchu człowieka wykazuje dużą dynamikę percepcji zmian ciśnienia akustycznego. Dolną granicę pola słuchowego człowieka w zakresie głośności stanowi tzw. próg słyszalności (próg detekcji sygnału). Jest to najmniejszy poziom ciśnienia akustycznego, który wywołuje spostrzegalne wrażenie słuchowe (przy braku innych dźwięków). Próg słyszalności nie jest wartością stałą - uzależniony jest od częstotliwości. Narząd słuchu człowieka jest najbardziej czuły na dźwięki w zakresie częstotliwości od 1000 do $4000 \mathrm{~Hz}$, natomiast dźwięki poniżej i powyżej tego zakresu mają nieco wyższy próg detekcji. Wartość progu słyszenia zależna jest również od czasu trwania dźwięku - im krótszy czas trwania, tym większa jest wartość progowa ciśnienia akustycznego [5]. Górną granicą pola słuchowego jest próg bólu (120-130 dB) [1].

Subiektywną oceną intensywności dźwięku jest głośność dźwięku. Jest to miara jakościowa, która pozwala na uszeregowanie dźwięków od najcichszego do najgłośniejszego. Głośność zależy od czynników takich jak poziom ciśnienia akustycznego, częstotliwość, szerokość pasma i czas trwania dźwięku, a także od czynników osobniczych, m.in. czułości słuchu.

W celu obiektywnej oceny głośności dźwięku wprowadzono pojęcie poziomu głośności oraz wyznaczono tzw. krzywe jednakowej głośności (izofony). Poziom głośności to wielkość, która jest porównawczą miarą głośności tonu w odniesieniu do głośności tonu wzorcowego (1000 $\mathrm{Hz}$ ). Wszystkie dźwięki, które są tak samo głośne jak ton wzorcowy, łączy się linią izofony [5].

Mechanizmy słuchowe odpowiedzialne za percepcję głośności nie zostały dokładnie poznane. Przyjmuje się, że głośność jest związana $\mathrm{z}$ aktywnością neuronów o częstotliwościach charakterystycznych zbliżonych do częstotliwości tonu oraz neuronów o podobnych częstotliwościach charakterystycznych [6].

Dyskryminacja głośności dźwięku jest jedną z podstawowych umiejętności układu słuchowego, która umożliwia między innymi ocenę odległości od źródła dźwięku i ocenę ruchomości źródła dźwięku. Ma również duże znaczenie w przypadku dźwięków mowy - za pomocą zmian natężenia dźwięku poszczególne fragmenty wypowiedzi mogą zostać zaakcentowane i podkreślone.

Relacje pomiędzy dyskryminacją wrażenia sensorycznego a zmianą natężenia bodźca badał niemiecki fizjolog Ernst Weber. Sformułował on tzw. prawo Webera, które stwierdza, że progowa zmiana głośności dźwięku jest proporcjonalna do jego wypadkowego natężenia. Oznacza to, że jeżeli natężenie bodźca nie jest duże, to już niewielka zmiana jego natężenia zostanie dostrzeżona. Natomiast jeśli początkowe natężenie dźwięku jest duże, zmiana natężenia również musi być bardzo duża, aby wywołać spostrzeżenie [za: 5]. Stosunek progowej wartości tej zmiany do początkowego natężenia dźwięku jest wielkością, która opisuje zdolność układu słuchowego do dyskryminacji zmian natężenia dźwięku [5].
Najlepsza zdolność dyskryminacji zmian natężenia dźwięku osiągana jest przy poziomach natężenia dźwięku około $40 \mathrm{~dB}$ SL. Szacuje się, że w tym zakresie układ słuchowy jest w stanie spostrzegać różnice natężenia równe ok. $10 \%$ natężenia początkowego (ok. 0,4 dB). Zdolność dyskryminacji przy progu słyszenia i dla dźwięków o dużych natężeniach jest znacznie niższa. Na dyskryminację zmian natężenia dźwięków ma wpływ również częstotliwość dźwięku (najlepsze progi różnicowania dla częstotliwości od 250 do $6000 \mathrm{~Hz}$ ), a także czas trwania bodźca (próg dyskryminacji maleje wraz ze wzrostem czasu trwania dźwięku) [1,5].

Układ słuchowy najczęściej przetwarza dźwięki złożone (np. dźwięki mowy i muzyki). Dźwięki złożone składają się z częstotliwości podstawowej oraz dodatkowych częstotliwości, tzw. składowych (harmonicznych). Układ słuchowy człowieka jest w stanie dostrzec zmiany intensywności nie tylko samego dźwięku złożonego jako całości, lecz także zmiany intensywności poszczególnych składowych. Średni próg dyskryminacji natężenia dla jednej składowej dźwięku złożonego wynosi ok. 1-2 dB. Zdolność dyskryminacji tak małych zmian możliwa jest dzięki zdolności detekcji zmian postaci widma sygnału. Układ słuchowy prawdopodobnie porównuje odpowiedzi pojawiające się na wyjściu różnych filtrów, dzięki czemu spostrzega zmianę odpowiedzi na wyjściu jednego z filtrów, podczas gdy odpowiedzi pochodzące $\mathrm{z}$ innych filtrów pozostają niezmienne [5].

Do tej pory nie zbadano dokładnie fizjologicznego mechanizmu dyskryminacji natężenia w układzie słuchowym. Może to mieć związek z szybkością wyładowań komórek nerwowych (wzrost intensywności sygnału powoduje wzrost szybkości wyładowań, jednak tylko do określonego zakresu intensywności) [2]. W procesie dyskryminacji natężenia mogą mieć również znaczenie informacje dostarczane przez neurony mające zbliżoną częstotliwość charakterystyczną do częstotliwości sygnału, a także synchroniczność fazowa [6].

\section{Dyskryminacja dźwięku w zakresie częstotliwości}

Pole słuchowe jest częścią pola dźwiękowego, która obejmuje zakres dźwięków słyszanych przez prawidłowo działający narząd słuchu człowieka. Przyjmuje się, że najniższa częstotliwość graniczna pola słuchowego wynosi $16 \mathrm{~Hz}$, natomiast za najwyższą słyszalną częstotliwość uważa się około 16-20 kHz (w zależności od wieku) [5].

Percepcja częstotliwości dźwięku odbywa się poprzez tzw. pasma krytyczne, które określają rozdzielczość częstotliwościową narządu słuchu. Pasma krytyczne rozmieszczone są na błonie podstawnej, a każde z pasm zawiera około 1300 neuronów.

Subiektywnym atrybutem częstotliwości jest wysokość dźwięku, która pozwala na uszeregowanie dźwięków na skali od niskich do wysokich [2]. Wrażenie wysokości dźwięku zależy przede wszystkim od częstotliwości tonu (w przypadku dźwięków tonalnych) lub częstotliwości podstawowej (w przypadku dźwięków złożonych). 
Wrażenie wysokości tonów, podobnie jak w przypadku głośności, podlega prawu Webera - takim samym różnicom $\mathrm{w}$ intensywności wrażeń odpowiadają takie same stosunki wielkości bodźców, które wywołują te wrażenia.

Wysokość tonu można wyznaczyć za pomocą skalowania, natomiast jednostką wysokości jest mel. Ustalono związek pomiędzy obiektywną skalą częstotliwości a subiektywną skalą wysokości tonu, przy założeniu, że dźwięk o częstotliwości $1000 \mathrm{~Hz}$ i poziomie ciśnienia akustycznego $40 \mathrm{~dB}$ ma wysokość równą 1000 melów [5].

Na wrażenie wysokości dźwięku, poza częstotliwością, ma wpływ także jego natężenie (np. dźwięki bardzo głośne odbierane są jako niższe). Dodatkowo, powstanie wrażenia wysokości dźwięku uwarunkowane jest jego minimalnym czasem trwania. Jeśli ton o danej częstotliwości podawany będzie bardzo krótko, to będzie odbierany jako niższy niż ten sam ton trwający znacznie dłużej. Średni czas trwania tonu niezbędny do prawidłowej oceny jego wysokości wynosi ok. $40 \mathrm{~ms}$ [5].

Zdolność układu słuchowego do spostrzegania zmian częstotliwości w czasie nazywana jest dyskryminacją częstotliwościową. Opiera się na dwóch teoriach - teorii miejsca i czasu. Percepcja częstotliwości związana jest z pobudzeniem błony podstawnej w określonym miejscu (informacja lokalizacyjna) oraz czasowym rozkładem impulsów nerwowych (informacja czasowa). Oba te czynniki umożliwiają precyzyjne rozpoznanie i dyskryminację częstotliwości. Na podstawie badań dyskryminacji słuchowej wyróżniono tzw. progi dyskryminacji, opisujące wartość najmniejszej spostrzeganej różnicy częstotliwości pomiędzy dwoma następującymi po sobie tonami. Progi dyskryminacji są najniższe $\mathrm{w}$ przypadku niskich częstotliwości, natomiast wraz ze wzrostem częstotliwości progi dyskryminacji są coraz wyższe

Percepcja wysokości dźwięków złożonych, w tym również mowy, jest bardziej skomplikowana. Percepcję dźwięków złożonych wyjaśniają dwie teorie - teoria czasu i teoria analizy. Teoria czasu opiera się na założeniu, że wrażenie wysokości dźwięków złożonych powstaje na podstawie analizy przez układ słuchowy odstępów czasowych pomiędzy kolejnymi wyładowaniami neuronów w nerwie słuchowym, odpowiadających drganiom tych obszarów błony podstawnej, w których składowe harmoniczne dźwięku złożonego nakładają się na siebie. Natomiast według teorii analizy wrażenie wysokości tworzone jest w układzie centralnym, który przetwarza sygnały neuronowe odpowiadające każdej składowej występującej w dźwięku złożonym [6].

\section{Dyskryminacja dźwięku w dziedzinie czasu}

Istotną rolę w procesie percepcji słuchowej pełni zmienność sygnału w dziedzinie czasu. Zmienność ta jest charakterystyczna szczególnie dla dźwięków mowy i muzyki. Układ słuchowy musi sprawnie analizować tę zmienność, ponieważ właśnie w tych fragmentach, które są zmienne, przenoszona jest większość istotnych informacji. Zdolność spostrzegania zmian struktury czasowej bodźca oraz zdolność do analizowania tych zmian umożliwia przede wszystkim tzw. rozdzielczość czasowa.
Rozdzielczość czasowa układu słuchowego związana jest ze spostrzeganiem zmian obwiedni widma dźwięku. Proces ten odnosi się do filtrowania sygnałów akustycznych na niższych piętrach układu słuchowego i zależy od porównania odpowiedzi pochodzących $\mathrm{z}$ różnych filtrów. Konieczność przetworzenia informacji w poszczególnych filtrach słuchowych oraz analiza informacji w wyższych piętrach drogi słuchowej wymaga określonego czasu powoduje to ograniczenie rozdzielczości czasowej układu słuchowego [5].

Pomiar rozdzielczości czasowej polega najczęściej na wyznaczeniu progów detekcji przerw (interwałów ciszy) w dźwiękach. Rozdzielczość czasowa układu słuchowego mieści się w zakresie od kilku do kilkunastu milisekund i jest uwarunkowana rodzajem bodźca dźwiękowego [2].

Pomiar rozdzielczości czasowej ucha polega na wyznaczeniu progów detekcji przerw (interwałów ciszy) w długotrwałych dźwiękach. W wielu eksperymentach dotyczących detekcji przerw wykorzystywano jako bodziec szum szerokopasmowy, ponieważ wprowadzenie przerw czasowych do takiego sygnału nie zmienia jego składu widmowego [13]. Dzięki temu jedynym czynnikiem umożliwiającym spostrzeganie takich przerw jest czas ich trwania. Wykazano, że najkrótszy interwał ciszy, jaki potrafimy spostrzec w takich warunkach, trwa około 2-3 ms [3].

Badania dyskryminacji czasu trwania dźwięków wykazały, że progi różnicowania u młodych osób dorosłych mieszczą się w zakresie 20-25 ms dla dźwięków o częstotliwości 250, 1000 i $4000 \mathrm{~Hz}$ i czasie trwania $200 \mathrm{~ms}$ [za: 4].

\section{Metody badania dyskryminacji}

Dyskryminacja jest zdolnością, która charakteryzuje nie tylko układ słuchowy, lecz także inne układy (np. wzrokowy). Metody badania dyskryminacji są wspólne dla różnego rodzaju modalności zmysłowych. W niniejszym podrozdziale zostaną przedstawione ogólne metody badania dyskryminacji słuchowej, które wykorzystywane są również w badaniu progów dyskryminacji innego rodzaju bodźców (z zachowaniem odpowiednich protokołów badań), natomiast testy przeznaczone do badania dyskryminacji słuchowej omówione zostaną w kolejnym podrozdziale.

Badania dyskryminacji słuchowej pozwalają przede wszystkim ocenić, jak efektywnie układ słuchowy koduje akustyczne parametry dźwięków. Progi różnicowania wyznaczone dla danej osoby mogą być porównane $\mathrm{z}$ wartościami normatywnymi, co umożliwia ocenę występowania ewentualnych dysfunkcji przetwarzania słuchowego. Dodatkowo, badania dyskryminacji częstotliwości i intensywności bodźców dźwiękowych są użyteczne w trakcie tworzenia modeli psychoakustycznych, które wskazują, jakie informacje o dźwięku są rozpoznawane przez ucho, a jakie nie. Modele te stanowią podstawę między innymi algorytmów oceny jakości transmisji mowy, kompresji dźwięków czy systemów automatycznie rozpoznających mowę [3].

Standardowo mianem progu określa się taki poziom cechy bodźca, powyżej którego jest on spostrzegany, natomiast poniżej już nie. $Z$ uwagi na fakt, że precyzyjne wyznaczenie 
takiego progu jest niezwykle trudne, zwykle oznacza się przedział, w obrębie którego słuchacz z określonym prawdopodobieństwem spostrzega dany sygnał. Do wyznaczania progu często stosuje się tzw. krzywą psychometryczną, która obrazuje zależność pomiędzy procentem spostrzegania bodźca a poziomem jego cechy. Progiem określa się taką wartość, przy której bodziec jest spostrzegany w 50\% (w niektórych metodach w 75-79\%) [2].

Wyróżnić można trzy klasyczne metody wyznaczania progu różnicowania intensywności: metodę stałych bodźców, metodę granic oraz metodę dostrajania, a także dodatkowo metodę zrównywania [2]. Warto również podkreślić, że w przypadku intensywności wyznaczyć możemy tzw. próg absolutny (próg detekcji bodźca) i próg różnicy (spostrzeganie zmiany bodźca) [2].

W przypadku metody stałych bodźców zadaniem słuchacza jest porównanie pary bodźców i określenie, który $\mathrm{z}$ nich wytwarza silniejsze wrażenie. W tej metodzie stosowane są dwa rodzaje bodźców - standardowy, o stałej wartości, oraz porównawczy, którego wartość się zmienia (jest mniejsza, większa lub równa bodźcowi standardowemu).

W metodzie granic również stosowane są bodźce standardowe i porównawcze, które prezentowane są parami. Intensywność bodźca porównawczego zmienia się o stałą wartość w kierunku intensywności bodźca standardowego (w seriach wstępujących bądź zstępujących).

Kolejna metoda - metoda dostrajania - również wykorzystuje bodźce standardowe i porównawcze. Zadaniem słuchacza jest dostrojenie intensywności bodźca porównawczego do intensywności sygnału standardowego, tak aby bodźce te były jednakowo głośne [2].

Dodatkowo wyróżnić można metodę zrównywania, w której słuchaczowi prezentowane są dwa różne bodźce do jednego i drugiego ucha. W jednym uchu prezentowany jest ton o określonej częstotliwości i intensywności, natomiast do drugiego ucha ton o innej częstotliwości. Zadaniem słuchacza jest dopasowanie intensywności tonu w drugim uchu do tonu podawanego do pierwszego ucha tak, aby tony były jednakowo głośne [2].

Progi dyskryminacji intensywności można wyróżnić również za pomocą metody detekcji modulacji amplitudy (ang. amplitude modulation, AM), w której zadaniem słuchacza jest określenie, czy w danym tonie wystąpiła modulacja, oraz za pomocą metody detekcji wzrostu intensywności. $\mathrm{W}$ tej metodzie słuchaczowi prezentowany jest ciągły bodziec o wzrastającej intensywności, a zadaniem słuchacza jest wskazanie, kiedy zauważył zmianę intensywności. Wynikiem badania jest wartość, o jaką musi wzrosnać intensywność bodźca, aby zmiana ta była spostrzegana.

Tradycyjne metody oceny dyskryminacji intensywności wykorzystują bodźce o jednej częstotliwości. Obecnie często stosuje się procedurę nazywaną analizą profilu (ang. profile analysis), w której prezentowany jest bodziec złożony, najczęściej z 21 składowych o częstotliwościach w zakresie 300-3000 Hz lub 200-5000 Hz. Składowe są w jednakowej odległości od siebie i mają jednakową amplitudę. Podczas badania prezentowane są dwa dźwięki - standardowy (wszystkie składowe o jednakowym natężeniu) oraz testowy, w którym jedna składowa ma wyższą intensywność niż pozostałe. W każdej próbie wyższą intensywność ma inna składowa o innej częstotliwości. Progi dyskryminacji intensywności dźwięku uzyskane metodą analizy profilu są niższe (lepsze) niż progi uzyskane klasycznymi metodami [3].

Progi różnicowania częstotliwości są powszechnie wyznaczane za pomocą dwóch metod: techniki modulacji częstotliwościowej (ang. frequency modulation, FM) oraz techniki następujących po sobie tonów. W technice następujących po sobie tonów słuchaczowi prezentowane są kolejno dwa tony, które różnią się nieznacznie częstotliwością. Zadaniem słuchacza jest wskazanie, który dźwięk był wyższy. Natomiast w technice modulacji częstotliwościowej prezentowane są tony modulowane częstotliwościowo (zwykle częstotliwość modulacji wynosi 2-4 Hz), zaś zadaniem słuchacza jest określenie, czy w danym tonie wystąpiła modulacja [2].

Najczęściej stosowaną metodą badania dyskryminacji czasu trwania dźwięku jest metoda wykrywania przerw w szumie (ang. Gap Detection Threshold, GDT). Zadaniem słuchacza jest określenie, czy słyszał dwa osobne sygnały czy jeden sygnał ciągły. Alternatywnie - w badaniu mogą być wykorzystane pary dźwięków, z których jeden zawiera przerwę. W tym przypadku zadaniem słuchacza jest wskazanie, który z usłyszanych sygnałów zawierał interwał ciszy [3].

Równie często w badaniach dyskryminacji czasu trwania dźwięków stosuje się metodę porównywania - prezentowane są dwa następujące po sobie tony, natomiast zadaniem słuchacza jest określenie, czy czas trwania dźwięków był taki sam, czy też dźwięki różniły się [4].

Inną metodą badania rozdzielczości czasowej może być procedura modulacji czasowej (ang. Temporal Modulation Transfer Function, TMTF). W badaniu tym prezentowane są dwa dźwięki (szumy szerokopasmowe), z których jeden jest bodźcem standardowym, natomiast drugi bodźcem testowym. Bodziec testowy jest modulowany amplitudowo (częstotliwość modulacji jest zmienna w kolejnych próbach). Zadaniem osoby badanej jest wskazanie bodźca modulowanego. Im większa jest częstotliwość modulacji, tym szybciej zmiany zachodzą w czasie - w ten sposób możliwy jest pomiar rozdzielczości czasowej układu słuchowego. Układ słuchowy człowieka jest najbardziej czuły na modulacje na poziomie $2-50 \mathrm{~Hz}$ [3].

Obecnie w badaniach dyskryminacji słuchowej coraz częściej stosuje się metody adaptacyjne, charakteryzujące się tym, że przebieg badania uzależniony jest od poziomu odpowiedzi słuchacza. Zarówno liczba obserwacji, jak i poziom prezentowanego $\mathrm{w}$ danej sekwencji bodźca są zdeterminowane danymi eksperymentalnymi. Metody adaptacyjne są proste i mają wysoką skuteczność, a ich zastosowanie warunkowane jest jednym założeniem, że prawdopodobieństwo prawidłowej odpowiedzi wzrasta wraz z poziomem bodźca [2].

Istnieje kilka metod adaptacyjnych, jednak procedura badania we wszystkich metodach jest zbliżona. Początkowa wartość bodźca jest na tyle wysoka, aby słuchacz nie 
miał problemów z udzieleniem prawidłowej odpowiedzi. Po udzieleniu poprawnej odpowiedzi wartość bodźca jest zmniejszana - aż do uzyskania odpowiedzi niepoprawnej. Wtedy wartość bodźca ulega zwiększeniu. Zmianę kierunku (wzrost lub zmniejszanie się) bodźca nazywa się zwrotem, natomiast wartość, przy której następuje zmiana punktem zwrotnym. Sekwencja o rosnących wartościach to tzw. grupa „w górę", natomiast seria o wartościach malejących to tzw. grupa „w dół” (dlatego metody adaptacyjne nazywane są często metodami góra-dół). Po uzyskaniu określonej liczby punktów zwrotnych oblicza się wartość progową [2].

Wśród metod adaptacyjnych wyróżnić można między innymi metodę schodów (ang. staircase method), metodę PEST (ang. Point Estimation by Sequential Testing) oraz metody alternatywnego wymuszonego wyboru (ang. alternative forced-choice methods).

Metoda schodów zbliżona jest do klasycznej metody granic. Poziom cechy bodźca zmniejszany jest do momentu uzyskania nieprawidłowej odpowiedzi, a następnie zwiększany do uzyskania odpowiedzi poprawnej. Próg różnicowania (na poziomie 50\%) wyznaczany jest za pomoca uśredniania wartości pozytywnych i negatywnych zwrotów wartości (ok. 6-8 zwrotów) [3].

Modyfikacją metody schodów są: technika PEST oraz procedura góra-dół. W metodzie PEST różnica pomiędzy bodźcami jest podwajana lub zmniejszana o połowę, w zależności od odpowiedzi słuchacza. O ile w metodzie schodów możliwe jest wyznaczenie progu na poziomie 50\% poprawnych odpowiedzi, o tyle metoda PEST pozwala na uzyskanie progu dla dowolnie wybranego punktu na krzywej psychometrycznej [3]. Również metoda góra-dól umożliwia uzyskanie progu dyskryminacji na poziomie powyżej 50\% (zwykle 71\%), jednak tylko wtedy, gdy zostaną zastosowane zmodyfikowane zasady wyznaczania punktu zwrotnego (w zależności od tego, czy słuchacz udzielił odpowiedzi poprawnej czy niepoprawnej) [3].

W badaniach psychoakustycznych często stosuje się metody wymuszonego wyboru, w których słuchacz zmuszony jest do udzielenia odpowiedzi (najczęściej „tak” lub „nie”). W badaniach dyskryminacji słuchowej stosuje się częściej metodę dwualternatywnego wymuszonego wyboru, w której zadaniem słuchacza jest wskazanie, w której z dwóch prezentowanych sekwencji bodźców obecny jest bodziec o określonych cechach. Zmiana wartości bodźca jest uzależniona od odpowiedzi słuchacza i zachodzi według ściśle określonych reguł [3].

\section{Polskie testy dyskryminacji słuchowej}

Z uwagi na złożoność testów dyskryminacji słuchowej nie są one powszechnie stosowane w praktyce klinicznej. $\mathrm{Z}$ tego powodu w Polsce nie jest dostępna duża liczba tego rodzaju testów. Wśród dostępnych testów możemy wyróżnić między innymi testy progów różnicowania intensywności (DLI), częstotliwości (DLF) i czasu trwania (DLD) dźwięków oraz test wykrywania przerw w szumie (GDT). Testy te opracowane zostały przez McPhersona, Senderskiego, Skarżyńskiego i Kochanka w Instytucie Fizjologii i Patologii Słuchu.
W testach DLF, DLI, DLD wykorzystywana jest procedura adaptacyjna. Stosowane są $\mathrm{w}$ nich dwa rodzaje bodźców - standardowy oraz zmienny. Bodziec zmienny zawiera dwa tony, które są takie same pod względem badanych cech (mają tę samą częstotliwość, intensywność oraz czas trwania), natomiast bodziec zmienny zawiera dwa tony, z których jeden różni się od drugiego jedną cechą (częstotliwością lub intensywnością lub czasem trwania). Różnica pomiędzy tonami zmienia się w zależności od odpowiedzi słuchacza - jeśli osoba badana prawidłowo oceni tony jako różne - wartość różnicy pomiędzy nimi zmniejsza się. Z kolei jeśli słuchacz uzna dwa tony w bodźcu zmiennym jako takie same - różnica pomiędzy tonami zwiększa się. Badanie składa się z dwóch faz - podczas fazy wstępnej słuchacz zapoznaje się $\mathrm{z}$ zadaniem oraz rodzajem stosowanych bodźców. W czasie fazy wstępnej ustalany jest również poziom różnicy pomiędzy bodźcami, od którego rozpocznie się właściwe badanie. We właściwym badaniu w losowej kolejności podawane są bodźce standardowe i zmienne, natomiast zadaniem słuchacza jest naciśnięcie na przycisk w momencie, kiedy usłyszy dwa różne tony. Wynikiem badania jest średnia wartość progu różnicy, dla której słuchacz określa dwa tony w bodźcu zmiennym jako różne. Szczegółowa procedura wyznaczania progów dyskryminacji intensywności, częstotliwości i czasu trwania dźwięków za pomocą testów DLI, DLD oraz DLF przedstawiona została w pracy Dajos i wsp. (2013) [26].

Test różnicowania przerw w szumie (GDT) również został opracowany $z$ wykorzystaniem procedury adaptacyjnej. Bodziec standardowy to szum szerokopasmowy o określonym czasie trwania (np. $500 \mathrm{~ms}$ ). Bodziec zmienny to szum szerokopasmowy z przerwą. W zależności od odpowiedzi słuchacza przerwa w szumie zmniejsza się (po odpowiedzi prawidłowej) lub zwiększa (po odpowiedzi nieprawidłowej). Zadaniem słuchacza jest wskazanie bodźca zmiennego. Próg dyskryminacji określa się jako średnią wartość czasu trwania przerwy, przy której słuchacz poprawnie wskazuje bodziec zmienny.

\section{Badania dyskryminacji słuchowej w praktyce eksperymentalnej i klinicznej}

Jako pierwszy badania dyskryminacji intensywności przeprowadził Riesz (1928) z użyciem tonów modulowanych amplitudowo. Prawo Webera zakłada, że stosunek $\Delta \mathrm{I} / \mathrm{I}$ (przyrost intensywności do początkowego poziomu intensywności) jest stały, bez względu na poziom bodźca i częstotliwość. W swoich badaniach Riesz i wsp. wykazali, że prawo Webera jest prawidłowe w przypadku niskich poziomów SL, natomiast w przypadku średnich i wysokich poziomów intensywności wyniki były „zbliżone” do prawa Webera. Oznacza to, że jeśli bodziec miał niewielką intensywność, wykrywane progi różnicy intensywności były stałe, natomiast jeśli bodziec miał większą intensywność, progi dyskryminacji różnicy intensywności zwiększały się (im głośniejszy bodziec, tym wyższy próg różnicowania). Podobne wyniki uzyskano również w innych badaniach, m.in. Moore’a i wsp. (1974), Jesteadta i wsp. (1977), Viemeistera i wsp. (1988) [za: 3]. Dodatkowo w badaniach Riesza i wsp. wykazano, że częstotliwość również ma wpływ na dyskryminację intensywności - stosunek $\Delta \mathrm{I} / \mathrm{I}$ dla częstotliwości do $1000 \mathrm{~Hz}$ zmniejszał się wraz ze wzrostem intensywności. Dla dźwięków o częstotliwościach wyższych 
(powyżej $1000 \mathrm{~Hz}$ ) stosunek $\Delta \mathrm{I} / \mathrm{I}$ pozostaje zgodny z prawem Webera [za: 3].

Badania dyskryminacji częstotliwości, intensywności i czasu trwania dźwięków prowadzili Bungert-Kahl i wsp. [7]. Oceniali oni progi różnicowania natężenia, częstotliwości i czasu trwania bodźców w grupie 100 osób w wieku 20-70 lat z wykorzystaniem tonów o różnych częstotliwościach. Progi dyskryminacji określane były dla trzech różnych rodzajów stymulacji: obuusznej (z międzyuszną różnicą bodźca), jednousznej oraz rozdzielnousznej. Wartości progów różnicowania częstotliwości, intensywności i czasu trwania dźwięków zwiększały się wraz z wiekiem. Wykazano również, że na progi różnicowania cech akustycznych dźwięków wpływa sposób prezentacji bodźca, np. podczas jednousznego badania dyskryminacji czasu trwania dźwięków progi różnicowania były stałe niezależnie od częstotliwości bodźca, jednak podczas tego samego badania z zastosowaniem stymulacji obuusznej i rozdzielnousznej progi różnicowania zmieniały się w zależności od częstotliwości sygnału. Progi różnicowania częstotliwości dźwięku zwiększały się wraz ze wzrostem częstotliwości, niezależnie od grupy wiekowej. Najniższe progi uzyskano dla częstotliwości poniżej $1000 \mathrm{~Hz}$, natomiast dla częstotliwości wyższych wartości progów różnicowania były znacznie wyższe [7].

Buss i wsp. [8] prowadzili badania dyskryminacji intensywności tonów w grupie osób dorosłych i dzieci w wieku szkolnym. W badaniach wykorzystano tony o częstotliwości $500 \mathrm{~Hz}$, z których jeden miał intensywność $65 \mathrm{~dB}$ SPL, natomiast drugi miał intensywność, która wzrastała o wartość równą $10 \log (\Delta \mathrm{I} / \mathrm{I})$. Podczas badania zastosowano procedurę 3-alternatywnego wymuszonego wyboru. Średnie progi różnicowania intensywności, tak jak zakładano, były lepsze u osób dorosłych niż u dzieci [8].

Shower i Biddulph (1931) jako pierwsi, za pomoca techniki modulacji częstotliwościowej, wyznaczyli progi różnicowania częstotliwości. Jednak kolejne badania (m.in. Harrisa i wsp., 1952; Moore'a i wsp., 1973; Wiera i wsp. 1977), z użyciem następujących po sobie tonów pulsujących, nie potwierdziły wyników badań Showera i wsp. prawdopodobnie ze względu na różnice $\mathrm{w}$ zastosowanej procedurze. Stosowanie bodźców modulowanych częstotliwościowo powoduje powstanie bodźców o nieco bardziej złożonej strukturze widmowej, co skutkuje nieco innym wzorcem kodowania nerwowego w porównaniu $\mathrm{z}$ tonami pulsacyjnymi. Ponadto na wartość progu różnicowania częstotliwości wpływają również intensywność i czas trwania sygnału [za: 3 ].

Progi różnicowania częstotliwości różnią się w zależności od częstotliwości dźwięku. Badania prowadzone przez Wiera i wsp. (1977) wykazały, że dla częstotliwości w zakresie 200-800 Hz progi różnicowania wynoszą ok. 1,5 Hz, dla częstotliwości 1000-2000 Hz około 2-3 Hz. Powyżej $1 \mathrm{kHz}$ wartości progów dyskryminacji wzrastały do ok. $18 \mathrm{~Hz}$, natomiast powyżej $4 \mathrm{kHz}$ do ok. $70 \mathrm{~Hz}$ [za: 3]. W badaniach Bungert-Kahl i wsp. [8] również wykazano, że niższe częstotliwości mają niewielkie progi dyskryminacji, natomiast progi różnicowania dla bodźców o częstotliwościach wyższych są zdecydowanie większe, np. dla częstotliwości $8 \mathrm{kHz}$ próg dyskryminacji częstotliwości wynosił od 196,7 Hz (osoby młode) do nawet $467 \mathrm{~Hz}$ (osoby w wieku podeszłym). Tak duże różnice $\mathrm{w}$ progach dyskryminacji częstotliwości związane są między innymi z teoriami słyszenia (teorie czasu i miejsca) [za: 3]. W przypadku niskich częstotliwości kluczowe znaczenie ma analiza synchroniczności fazowej, która występuje dla bodźców o częstotliwościach niższych niż $5 \mathrm{kHz}$. Natomiast dla częstotliwości wyższych układ słuchowy analizuje informacje o miejscu pobudzenia błony podstawnej, które są znacznie mniej precyzyjne niż informacje czasowe.

Dai i wsp. [9] oceniali funkcje psychometryczne dla dyskryminacji częstotliwości tonów. Badania z użyciem metody adaptacyjnej wykonywali u 5 dorosłych, prawidłowo słyszących osób, stosując różne poziomy intensywności bodźca i w szerokim zakresie częstotliwości. Dla każdej badanej częstotliwości autorzy określali próg dyskryminacji. W badaniach wykazano istotną zależność pomiędzy czułością (d') i wielkością różnicy częstotliwości $(\Delta \mathrm{F})$. Badania te potwierdziły hipotezę, że funkcja psychometryczna dyskryminacji częstotliwości, określona przez zależność pomiędzy d' i $\Delta \mathrm{F}$, jest liniowa [9].

Arlinger i wsp. [10] oceniali zdolność układu słuchowego do detekcji zmian częstotliwości tonów ciągłych modulowanych częstotliwościowo o różnym czasie trwania. Średnie progi dyskryminacji były nieco lepsze dla tonów o czasie trwania krótszym niż 200 ms, natomiast słabsze dla tonów dłuższych niż 200 ms. Autorzy sugerują, że niższe progi dyskryminacji dla krótkich bodźców wynikają z tego, że dyskryminacja opiera się na analizie różnicy pomiędzy częstotliwością bazową a częstotliwością plateau. Z kolei w przypadku bodźców o dłuższym czasie trwania dyskryminacja zależy od rzeczywistych zmian częstotliwości [10].

Hartmann i wsp. [11] porównywali wyniki badań progów dyskryminacji częstotliwości krótkich tonów uzyskanych za pomoca dwóch metod - dopasowania wysokości oraz rozróżniania częstotliwości. Badania wykazały, że progi dyskryminacji określone za pomocą metody dopasowania wysokości były lepsze niż te uzyskane w metodzie rozróżniania częstotliwości. Autorzy sugerują, że w procesie dopasowania wysokości oprócz wymiaru wysokości używany jest prawdopodobnie również wymiar barwy, który ułatwia dyskryminację [11].

Z kolei Sęk i wsp. [12] oceniali dyskryminację częstotliwości w zakresie od 250 do $8000 \mathrm{~Hz}$ przy użyciu trzech metod: testu dyskryminacji częstotliwości (ang. Difference Limen for Frequency, DLF), testu dyskryminacji zmian częstotliwości (ang. Difference Limen for Change, DLC) oraz testu modulacji częstotliwościowej. W badaniu DLF zadaniem słuchacza było określenie, który z dwóch następujących po sobie tonów miał wyższą częstotliwość. Z kolei w badaniu DLC prezentowano dwie pary tonów. W jednej parze były dwa jednakowe tony, natomiast w drugiej parze dwa tony różniące się wysokością (częstotliwością). Zadaniem słuchacza było wskazanie, która z par zawierała różne bodźce. Dla częstotliwości niższych od $2 \mathrm{kHz}$ progi DLF i DLC były bardzo niskie (mniej niż 0,6\% częstotliwości badanej), natomiast dla częstotliwości wyższych od $4 \mathrm{kHz}$ wartości progów znacznie wzrastały. Wyniki testu modulacji częstotliwości były mniej zależne od częstotliwości bodźca. Progi uzyskane w tym badaniu były wyższe 
niż w badaniach DLF i DLC w przypadku częstotliwości mniejszych niż $2000 \mathrm{~Hz}$ oraz niższe dla częstotliwości powyżej $4000 \mathrm{~Hz}$ [12].

He i wsp. [14] opracowywali funkcje psychometryczne dla detekcji przerw w szumie. Autorzy oceniali wpływ czasu trwania szumu oraz lokalizacji przerwy na wyniki testu GDT (dyskryminacja przerw w szumie) u zdrowych osób dorosłych. Wyniki wykazały, że progi dyskryminacji przerw w szumie ulegają poprawie wraz ze wzrostem czasu trwania bodźca, natomiast lokalizacja przerwy w szumie nie wpływa na uzyskiwane wyniki [14].

Rammsayer i wsp. [15] w swoich badaniach z użyciem metody adaptacyjnej stosowali bodziec składający się z dwóch interwałów o różnym czasie trwania. Interwały wypełnione stanowił ton ciągły o częstotliwości $1000 \mathrm{~Hz}$. W tzw. interwałach pustych za pomocą trzasku sygnalizowano jedynie początek i koniec bodźca (pomiędzy trzaskiem początkowym i końcowym panowała cisza). Zadaniem osoby badanej było wskazanie, który z dwóch interwałów miał dłuższy czas trwania. Wykazano, że interwały wypełnione (tony ciągłe) są dyskryminowane bardziej precyzyjnie niż interwały puste. Dyskryminacja interwałów wypełnionych o dłuższym czasie trwania pozostawała pod wpływem procesów poznawczych (w przeciwieństwie do interwałów o krótszym czasie trwania) [15].

Lapid i wsp. [16] porównywali różne metody oceny dyskryminacji czasu trwania dźwięku. Badania wykazały, że różne metody uzyskiwania progów różnicowania czasu trwania dźwięków dają zbliżone wyniki.

Griffiths i wsp. [17] opracowali zestaw testów percepcji czasowej i przestrzennej dla osób z uszkodzeniami neurologicznymi - NAB (ang. Newcastle Auditory Battery). Zestaw pozwala na ocenę poprawności wykonania zadania poprzez porównanie wyniku z wynikiem grupy kontrolnej. W testach percepcji czasowej wykorzystywano tony o częstotliwości $500 \mathrm{~Hz}$, modulowane amplitudowo lub częstotliwościowo.

\section{Dyskryminacja słuchowa u osób z uszkodzeniem słuchu}

Badania dyskryminacji słuchowej prowadzone są zwykle u osób o prawidłowym słuchu. Jednak w ostatnim czasie testy dyskryminacji słuchowej wykonywane są również u osób $\mathrm{z}$ obwodowymi ubytkami słuchu, a także u osób z zaburzeniami ośrodkowego układu słuchowego.

Badania wykazały, że u osób z obwodowymi ubytkami słuchu progi dyskryminacji częstotliwości są znacznie większe niż u osób z prawidłowym słuchem [za: 18]. Trudno jednak stwierdzić, czy podwyższenie progów dyskryminacji spowodowane jest obwodowym ubytkiem słuchu, czy też istnieją zmiany w układzie słuchowym, które powodują słabsze przetwarzanie informacji dotyczących częstotliwości dźwięku.

Halliday i wsp. [19] oceniali zdolność różnicowania częstotliwości u dzieci z czuciowo-nerwowym ubytkiem słuchu w stopniu lekkim i umiarkowanym oraz wpływ tych zdolności na umiejętności językowe (m.in. czytanie). Badania wykazały, że dzieci z ubytkami słuchu mają słabsze zdolności dyskryminacji częstotliwości niż dzieci z grupy kontrolnej. Jednak wpływ tych deficytów na czytanie i umiejętności językowe nie był oczywisty - analiza wyników nie wykazała istotnych korelacji pomiędzy umiejętnością dyskryminacji słuchowej a zdolnościami językowymi, jeśli oceniano obie grupy oddzielnie [19].

Simon i wsp. [20] badali progi dyskryminacji częstotliwości u osób z ubytkami słuchu. Wykazali oni, że biorąc pod uwagę ogólne wyniki, korelacja pomiędzy progiem słyszenia a progiem dyskryminacji była jedynie umiarkowana. Biorąc jednak pod uwagę wyniki dla poszczególnych częstotliwości, większe korelacje wykazano pomiędzy progami różnicowania częstotliwości i progiem ubytku słuchu dla częstotliwości powyżej $1000 \mathrm{~Hz}$. W przypadku częstotliwości niższych od $1000 \mathrm{~Hz}$ progi dyskryminacji były mniej zależne od progu słyszenia [20].

Badania wykazały, że ubytek słuchu nie wpływa na rozdzielczość czasową układu słuchowego - progi GDT są zbliżone $\mathrm{u}$ osób $\mathrm{z}$ ubytkami słuchu i u osób ze słuchem prawidłowym [3,21]. Wyniki tych badań potwierdzają teorię, że procesy związane $\mathrm{z}$ rozdzielczością czasową zachodzą na wyższych piętrach drogi słuchowej, ponieważ uszkodzenie obwodowego układu słuchowego nie wpływa na progi dyskryminacji przerw w szumie.

W różnych pracach wykazano natomiast istotny wpływ wieku na progi dyskryminacji czasu trwania bodźców dźwiękowych GDT - osoby w wieku podeszłym (bez ubytków słuchu) osiągają wyższe progi dyskryminacji przerw $\mathrm{w}$ szumie $\mathrm{w}$ porównaniu $\mathrm{z}$ osobami młodszymi $[21,22]$. Badania te dowodzą, że wraz z wiekiem zmniejsza się zdolność przetwarzania czasowego dźwięków, co znajduje odzwierciedlenie $\mathrm{w}$ trudnościach $\mathrm{z}$ rozumieniem mowy [3].

W badaniach oceniajacych wpływ jednostronnego uszkodzenia ośrodkowego układu słuchowego na zdolności dyskryminacji słuchowej wykazano, że u osób z uszkodzeniem prawej półkuli mózgu dyskryminacja częstotliwości dźwięku jest obniżona w porównaniu z osobami $\mathrm{z}$ uszkodzeniem lewej półkuli oraz z osobami zdrowymi. Interesujące jest to, że w badaniach tych wyniki osób z uszkodzeniami lewej półkuli mózgu nie różniły się znacząco od wyników osób z grupy kontrolnej. Z kolei w podobnych badaniach Thompson i wsp. (1992) wykazali odwrotną zależność progi różnicowania osób z uszkodzeniem lewej półkuli różniły się znacznie od progów uzyskanych w grupach osób zdrowych i z uszkodzeniami prawej półkuli, a wyniki osób z deficytami prawej półkuli były bardziej zbliżone do wyników grupy kontrolnej [za: 18].

Odmienność wyników u osób z zaburzeniami ośrodkowego układu słuchowego może być spowodowana różnicami w stosowanych procedurach i metodach badania. Johnsrude i wsp. (2000) wykazali, że na wyniki badania dyskryminacji częstotliwości wpływa złożoność zastosowanych testów. Badali oni grupę osób z zaburzeniami neurologicznymi z użyciem dwóch testów dyskryminacji w pierwszym zadaniem pacjentów było określenie, czy dwa prezentowane dźwięki się różnią, natomiast w drugim badaniu słowne określenie, czy drugi z podawanych dźwięków jest wyższy czy niższy od pierwszego. Osoby 
z zaburzeniami neurologicznymi uzyskały słabsze wyniki niż osoby $\mathrm{z}$ grupy kontrolnej jedynie $\mathrm{w}$ drugim teście (bardziej złożonym) [za: 18].

Rota-Donahue [23] oceniała zdolność dyskryminacji częstotliwości u dzieci z ośrodkowymi zaburzeniami przetwarzania słuchowego (C)APD oraz u dzieci z opóźnionym rozwojem mowy (ang. Specific Language Impairment, SLI) za pomocą testów behawioralnych oraz testu elektrofizjologicznego potencjałów niezgodności MMN. W obu badaniach wykorzystywano ton o częstotliwości podstawowej $1000 \mathrm{~Hz}$. Badania wykazały, że dzieci z zaburzeniami przetwarzania słuchowego (C)APD i dzieci z SLI mają słabsze wyniki (tzn. gorzej różnicowały tony) w testach behawioralnych oraz mniejsze amplitudy potencjałów w teście MMN w porównaniu z dziećmi z grupy kontrolnej [23].

Noonan i wsp. [24] oceniali związek pomiędzy dyskryminacją częstotliwości i poziomem rozwoju językowego u dzieci w wieku 5-7 lat. Badania wykazały duże zróżnicowanie zdolności dyskryminacji częstotliwości u dzieci w tej grupie wiekowej. Autorzy wykazali, że istnieje negatywna korelacja pomiędzy zdolnościami dyskryminacji częstotliwościowej i zdolnościami językowymi, co oznacza, że dzieci, które mają słabsze progi różnicowania częstotliwości, osiągnęły również słabsze wyniki w teście recepcji i ekspresji językowej [24].

Badania dowiodły, że istnieje związek pomiędzy uszkodzeniami ośrodkowego układu słuchowego i dyskryminacją czasu trwania dźwięków. Osoby dorosłe z uszkodzeniami lewej półkuli osiągały progi dyskryminacji długości rzędu $200 \mathrm{~ms}$, podczas gdy zdrowe osoby dorosłe - około $50 \mathrm{~ms}$.
Wyższe progi dyskryminacji obserwowano również u osób z uszkodzeniami prawej półkuli (ok. 100 ms), jednak różnica ta nie była tak znacząca [za: 4].

Musiek i wsp. [25] prowadzili badania w grupie osób ze słuchem prawidłowym i uszkodzeniami ośrodkowego układu nerwowego. Wyniki wykazały, że u osób z uszkodzeniami ośrodkowego układu nerwowego progi detekcji przerw w szumie są istotnie wyższe niż u osób zdrowych (odpowiednio ucho prawe - 7,8 ms i ucho lewe $-8,5 \mathrm{~ms}$ oraz ucho prawe $-4,8 \mathrm{~ms}$ i ucho lewe $-4,9 \mathrm{~ms}$ ) [25].

\section{Podsumowanie}

Badania dyskryminacji słuchowej, chociaż nie są wykorzystywane powszechnie w praktyce klinicznej, mogą dostarczyć wiele informacji dotyczących funkcjonowania układu słuchowego, szczególnie jego ośrodkowej części. Istnieje wiele metod oceny zdolności dyskryminacji słuchowej, z których obecnie najpopularniejsze są metody adaptacyjne. Badania dyskryminacji słuchowej pozwalają ocenić, jak efektywnie układ słuchowy przetwarza akustyczne cechy dźwięków. Deficyty dyskryminacji słuchowej mogą powodować trudności z rozumieniem mowy, nawet przy prawidłowej czułości słuchu. Konieczne są dalsze badania, które pozwolą poznać mechanizmy przetwarzania słuchowego, w tym także dyskryminacji słuchowej.

Publikacja powstała $w$ związku $z$ realizacja projektu pn. „Zintegrowany system narzędzi do diagnostyki i telerehabilitacji schorzeń narządów zmystów (słuchu, wzroku, mowy, równowagi, smaku, powonienia)" INNOSENSE, wspótfinansowanego przez Narodowe Centrum Badań i Rozwoju w ramach Programu STRATEGMED.

\section{Piśmiennictwo:}

1. Lindner G. Podstawy audiologii pedagogicznej. Warszawa: PWN; 1976.

2. Jorasz U. Wykłady z psychoakustyki. Poznań: Wydawnictwo Naukowe Uniwersytetu im. Adama Mickiewicza; 1998.

3. Hurley RM, Fulton SE. Psychoacoustic considerations and implications for the diagnosis of (Central) Auditory Processing Disorder. W: Musiek FE, Chermak GD, red. Handbook of (Central) Auditory Processing Disorder. Auditory Neuroscience and Diagnosis, vol. 1. Plural Publishing Inc., 2007; s. 13-52.

4. Musiek F. Pathways: auditory duration discrimination: Time to take a close look? Hearing Journal, 2013; 66(5): 19-20.

5. Ozimek E. Dźwięk i jego percepcja. Aspekty fizyczne i psychoakustyczne. Warszawa-Poznań: PWN; 2002.

6. Moore BC. Wprowadzenie do psychologii słyszenia. Warszawa-Poznań: PWN, 1999.

7. Bungert-Kahl P, Biedermann F, Dörrscheidt GJ, von Cramon D, Rübsamen R. Psychoacoustic test tools for the detection of deficits in central auditory processing: Normative data. Z Audiol, 2004; 43(2): 48-71.

8. Buss E, Hall III JW, Grose J. Psychometric functions for pure tone intensity discrimination: Slope differences in school-aged children and adults. J Acoust Soc Am, 2009; 125(2): 1050-58.

9. Dai H, Micheyl C. Psychometric functions for pure-tone frequency discrimination. J Acoust Soc Am, 2011; 130(1): 263-72.
10. Arlinger S, Jerlvall L, Ahren T, Holmgren E. Thresholds for linear frequency ramps of a continuous pure tone. Acta Otolaryngol, 1977; 83: 317-27.

11. Hartmann W, Rakerd B, Packard T. On measuring the frequency-difference limen for short tones. Percpet Psychophys, 1985; 38(3): 199-207.

12. Sęk A, Moore BCJ. Frequency discrimination as a function of frequency, measured in several ways. J Acoust Soc Am, 1995; 97(4); 2479-86.

13. Sęk A, Skrodzka E, Marszałkiewicz M. Psychoakustyka w pigułce. Instytut Akustyki UAM; 2000.

14. He NJ, Horwitz AR, Dubno JR, Mills JH. Psychometric functions for gap detection in noise measured from young and aged subjects. J Acoust Soc Am, 1999; 106(2): 966-78.

15. Rammsayer TH, Lima SD. Duration discrimination of filled and empty auditory intervals: cognitive and perceptual factors. Percept Psychophys, 1991; 50(6): 565-74.

16. Lapid E, Ulrich R, Rammsayer $T$. On estimating the difference limen in duration discrimination tasks: a comparison of the 2AFC and the reminder task. Percept Psychophys, 2008; 70(2): 291-305.

17. Griffiths T, Dean J, Woods W, Rees A, Green G. The Newcastle Auditory Battery (NAB): a temporal and spatial test battery for use on adult naïve subjects. Hear Res, 2001; 154: 165-69.

18. Nagle S. Frequency discrimination and (C)APD. Hearing Journal, 2009; 62(2): 36. 
19. Halliday LF, Bishop DVM. Frequency discrimination and literacy skills in children with mild to moderate sensorineural hearing loss. J Speech Lang Hear Res, 2005; 48: 1187-203.

20. Simon HJ, Yund EW. Frequency discrimination in listeners with sensorineural hearing loss. Ear and Hearing, 1993; 14(3): 190-201.

21. Fitzgibbons PJ, Gordon-Salant S. Age effects on measures of auditory duration discrimination. J Speech Hear Res, 1994; 37: 662-70.

22. Phillips SL, Gordon-Salant S, Fitzgibbons PJ, Yeni-Komshian GH. Auditory duration discrimination in young and elderly listeners with normal hearing. J Am Acad Audiol, 1994; 5: 210-15.

23. Rota-Donahue C. Neurophysiological bases of frequency discrimination in children with Auditory Processing Disorder or Specific Language Impairment. Dissertation submitted to the Graduate Faculty in Speech-Language-Hearing Sciences in partial fulfillment for the Degree of Doctor of Philosophy. The City University of New York, 2014, http://academicworks. cuny.edu/cgi/ viewcontent.cgi?article $=1101$ \& context $=g c \_e t d s$

24. Noonan K, Bavin EL, Ong B, Grayden D. The relationship between frequency discrimination skills and language development in 5-7 year olds. University of Reading, Proceedings of the Child Language Seminar $2007-30^{\text {th }}$ Anniversary, 114-24.

25. Musiek FE, Shinn JB, Jirsa R, Bamiou DE, Baran JA, Zaidan E. GIN (Gaps-In-Noise) Test performance in subjects with confirmed central auditory nervous system involvement. Ear Hear, 2005; 26: 608-18.

26. Dajos K, Piłka A, Senderski A, Kochanek K, Skarżyński H. Wyniki testów ośrodkowych funkcji słuchowych u dzieci i młodzieży w wieku szkolnym. Otorynolaryngologia - przegląd kliniczny, 2013; 12(3): 121-28. 